\title{
The Effects of Reciprocal Peer Tutoring on Chemistry Students' Achievement and Retention in Chemical Kinetics in Jos Metropolis, Nigeria
}

\author{
Ephraim J. Gongden, Ph.D \\ Department of Science and Technology Education, University of Jos, P.M.B 2087, Jos - Plateau State Nigeria \\ Tel: +234703 008 7027; *E-mail: gongdenej@yahoo.com
}

\begin{abstract}
This study investigated the effect of reciprocal peer tutoring (RPT) strategy on chemistry students' achievement and retention in chemical kinetics in Jos metropolis. It specifically attempted to determine and compare the achievements of students exposed to RPT and conventional teaching. The quasi-experimental design, specifically the pretest-posttest - control group design was used. The sample consisted of 86 students drawn from two randomly selected secondary schools. There were 41 students in the control class and 46 in the experimental class. A chemical kinetics achievement test (CKAT) was used to collect data from respondents and the data was analyzed using mean, standard deviation and t-test at 0.05 level of significance. The study revealed that the students exposed to RPT significantly achieved better than those exposed to conventional teaching. Similarly, those students that were taught using RPT were significantly better than those exposed to conventional teaching in the retention of what was taught them after four weeks. There was no significant difference in the achievement and retention of male and female students taught using RPT strategy. The study concluded that the achievement and retention of male and female chemistry students of the students is enhanced when exposed to reciprocal peer tutoring strategy. It is recommended that reciprocal peer tutoring strategy should be used by chemistry teachers in order to improve the achievement and retention of male and female chemistry students in the subject. Furthermore, a study should be conducted to find out the effect of varying RPT on students' achievement and retention in chemistry.
\end{abstract}

Keywords: Reciprocal peer tutoring, achievement, retention, chemical kinetics

DOI: $10.7176 / \mathrm{JEP} / 12-24-13$

Publication date:August $31^{\text {st }} 2021$

\section{Introduction}

Education has been considered an instrument for economic, political, social, technological and scientific development of all nations (Gongden, 2015). This may account for the huge investments by governments on the education sector and the various educational policies formulated by governments. Over the past decades the Federal Ministry of Education launched several development programmes targeted at enhancing the quality of education in the country. Some of the major attempts to enhance the quality of education at the primary and secondary school levels implemented are: establishment of universal basic education boards, (UBEBs), provision of furniture, renovation and building new classrooms, staffing primary and secondary schools with academically competent teachers, strengthening teacher and leaders training, encouraging curriculum revision and higher quality textbooks development. These are all in addition to the National Policy on Education which emphasized the teaching of sciences in its National Policy on Education (FGN, 2008). The emphasis on the sciences is necessitated by the importance of science and technology in the life of a nation. Chemistry as one of the branches of pure science deals with the structure, compositions, properties, reactions, uses of matter and the principles governing the changes which matter undergoes. The effective teaching and learning of chemistry is crucial for the overall development of any society. This is because of the central role that chemistry plays in the field of science and technology. Jegede (2007) and Ojokuku (2012) stressed that chemistry occupies a central position among the sciences due to its remarkable contribution in medicine, pharmacy, textile industry, engineering, petroleum, and agriculture to mention but a few. As a result of this, many nations hope to achieve technological advancement and self-reliance for her citizens through science and chemical education (Fatokun, Onwoke \& Hudu, 2018). Unfortunately, students' persistent under achievement in chemistry in external examinations like the West African Senior School Certificate Examination (WASSCE) and the National Examination Council (NECO) is quite disturbing and this has been a major concern. Despite all the efforts of the Federal Government of Nigeria, there still exist some report of poor academic performance among secondary school students in public examinations in sciences (Gongden, 2015).

Many factors have been suggested for the poor achievement. Students' under-achievement in chemistry might probably be associated with some concepts that are perceived by students as difficult like chemical kinetics. 
There has been a reoccurring candidates' weakness identified, such as; confusion over the units of rate of reactions, inability to calculate reaction rates, poor knowledge of factors affecting reaction rates, inability to derive the equilibrium constant expression and the use of it during calculations among others (WAEC Chief Examiners' report, 2015, 2017, 2016, 2018). Chemical kinetics, also known as reaction kinetics, is the branch of physical chemistry that is concerned with understanding the rates of chemical reactions. It tells us the speed at which chemical species transform into new species with the breaking and formation of chemical bonds. It includes investigations of how experimental conditions influence the speed of a chemical reaction and yield information about the reaction mechanism and transition states. The study of chemical kinetics has been highly useful in determining the factors that influence the rate, maximum yield and conversion in industrial processes. The mechanism or the sequence of steps by which the reaction occurs can be known. It is also useful in selecting the optimum conditions for maximum rate and yield of the chemical process. It helps us understand the rates of reactions and how it is influenced by certain conditions. It further helps to gather and analyze the information about the mechanism of the reaction and define the characteristics of a chemical reactions.

Other factors include; the learning environment, the conceptual nature of Chemistry and this may not be unconnected with the use of inappropriate, teachers and students' interest, lack of motivation, abstract nature of chemistry, and the lack of qualified chemistry teachers amongst others. Gongden and Gongden (2019) noted that the most important factor is the ineffective teaching methods in use by Chemistry teachers. Most of the chemistry teachers make use of the usual conventional teaching approach (lecture) instead of student - centered strategies. A shift is therefore advocated by researchers to methods that will enable the learner to construct his/her own understanding (Samba \& Eriba, 2012; Nnorom, 2015). As a result of this, researchers have sought to develop various teaching and learning strategies that are rooted in constructivism. Among these strategies is cooperative learning, inquiry approach, experimentation, etc. Cooperative learning is a comprehensive approach to teaching that derives from a theory of education and encompasses key assumptions about what students should learn and how they learn. It is a strategy in which students work together in small teams and use a number of activities to achieve stated objectives and improve their understanding of subject matter (Fatokun, Onwoke \& Hudu, 2018). Most cooperative approaches involve heterogeneous teams, usually of four or five members, working together towards a group task in which each member is individually accountable for part of an outcome that cannot be completed unless the members work together (Sani, 2015). Lessons in the cooperative learning strategy are arranged so that each student, ranging from the fastest to the slowest learner, has a contribution to make. Various types of cooperative learning strategies exist. One of such is Peer Tutoring. Peer tutoring is a student mediated instructional procedure in which small learning groups work together on learning tasks (Dufrene, Noell, Gilbertson \& Duhon 2005). Peer tutoring instructional method is the process by which a learner, with guidance from a teacher helps one or more students at the same grade level to learn a skill or concept (Paul, Lisa \& Vanesa, 2006). It is basically a cognitive apprenticeship between an expert and a novice. Tutoring can take place between a more-skilled child and a less skilled child. Peer tutoring is an instructional strategy that consists of student's partnership, where a student teach his peers, linking high achieving students with lower achieving students or those with comparable achievements. The pairing of higher and lowerachieving students is intended so that students gain knowledge from each other through practice and reinforcement (Jibrin \& Zayum, 2012). In all exercise involved in peer tutoring the teacher serve as a facilitator. Individual tutoring is an effective strategy that benefits many students, especially those who are not doing well in a subject. Peer tutoring is distinguished from other forms of peer learning or cooperative learning in that peers are taking specific roles as tutor or tutee (Topping, 2005; Okparaugo, 2017). These roles can be fixed in which one with a little bit higher status or prior information always take the tutor role and others always receive the teaching and hence are tutees. In a pair group or small group conditions, roles can be exchanged and therefore we call that kind of peer tutoring a reciprocal peer tutoring (Topping, 2005). Reciprocal Peer Tutoring (RPT) is a form of cooperative learning, in which students function reciprocally as both tutor and tutee (Ogbuanya, Bakare \& Igweh, 2009 and Obiunu, 2008). This dual role is beneficial because it enables students to gain from both the preparation and the instruction in which tutors engage and from the instructions that tutees receive. According to Ogbuanya et al (2009), RPT helps teachers to cope with challenges such as limited instructional time, multiple curricular requirements, and appropriate social engagement among learners. The use of peer tutoring is theoretically underpinned by Vygotsky's (1978) social construction of knowledge mediated using language and concept of zone of proximal development (Alemu, 2020). In peer tutoring settings, both the tutor and the tutee have the opportunity to use common language in conjunction to the specialized language of science to investigate science concepts in a level social plane. This is in contrast to the objectivist science teaching in which the teacher uses highly specialized language of science in precise and unchanging ways of describing the working of the "real world" with the attempt to transfer knowledge directly from the teacher's mind to students' mind. Under the latter case students are expected to internalize the right explanation of nature and the right way of solving problems and reproduce them in the precise language of the teacher during assessment of learning 
(Gillies \& Ashman, 2003).

One of the factors that affect students' achievement is gender. The issue of gender is an important one in science education especially with increasing emphasis on boosting manpower for technological advancement (Isah, 2013). Gender is the physical and behavioral difference that distinguishes individual organism according to their functions in the reproductive process. Several reports abound on the trend of students' achievement based on gender. While some studies placed male students ahead of females counterparts in terms of academic achievement, some studies put them at par while others put the female students' achievement ahead of the male students. It is not clear how male and female students will achieve when taught chemical kinetics using reciprocal peer tutoring.

Peer tutoring has been shown to increase significantly students' time spent in academic instruction and engagement (Egbockuku and Obiunu, 2006; Oludipe, 2007, Ogbuanya, Bakare \& Igweh, 2009). Learning in peer tutoring, where the overwhelming academic posture of the teacher is not forcing students to play passive roles, is facilitated because of the classroom environment that allows further knowledge elaboration and elicitation (Cheng \& Ku, 2009; Neugebauer et al., 2016). Science educators such as Ayuba (2011) considered peer tutoring as one of the effective and powerful instructional method that can be used to develop academic as well as social skills in both the tutor and the tutee (the learner). Despite the positive report of the use of RPT, the academic achievement of students has not improved appreciably. There is also scarcity of report on its efficacy on chemistry students' achievement and retention when used to teach students chemical kinetics in Jos - Plateau state. Since learner-centered strategies tend to enhance understanding, achievement and retention of content learnt, this study seeks to determine the effects of reciprocal peer tutoring strategies on male and female chemistry students' achievement and retention in chemical kinetics.

\subsection{Research Questions}

The following research questions were raised to guide the study:

i. What is the pretest mean achievement scores of students taught chemical kinetics using RPT and those taught directly by teachers in a chemical kinetics achievement test (CKAT)?

ii. What is the posttest mean achievement scores of students taught chemical kinetics using RPT and those taught directly by teachers?

iii. To what extent do male and female students differ in their mean achievements scores in a CKAT when taught using RPT?

iv. What is the mean difference in the retention scores of students taught chemical kinetics using RPT with students taught directly by teachers?

v. What is the mean difference in retention scores of male and female students taught chemical kinetics using RPT?

\subsection{Research Hypotheses}

i. There is no significant difference between the pretest mean achievement scores of students taught chemical kinetics using RPT and those taught directly by teachers

ii. There is no significant difference between the posttest mean achievement scores of students taught chemical kinetics using RPT and those taught directly by teachers

iii. There is no significant difference between the posttest mean achievement scores of male and female students taught chemical kinetics using RPT

iv. There is no significant difference between the posttest mean retention scores of students taught chemical kinetics using RPT and those taught directly by teachers

v. There is no significant difference between the posttest mean retention scores of male and female students taught chemical kinetics using RPT

\section{Methods}

The research design used for this study was the quasi-experimental design. Specifically, was the pretestposttest - control group design. This design was used because it allows utmost control of extraneous variables (Nworgu, 2006). A true experimental study was not possible because complete randomization of students was not be possible as it would have disrupted the school's arrangements. Therefore, intact classes were used as experimental and control groups. A total of eighty-six (86) students were involved in the study. This sample was obtained from two schools that were randomly selected for the study. Random sampling method was employed to assign the schools into control and experimental groups respectively. The control class had forty-one (41) students made up of nineteen (19) females and twenty-two (22) males), while the experimental class had fortyfive (45) students consisting of twenty-one (21) females and twenty-four (24) males. 
Both groups were first administered a pretest using the chemical kinetics achievement test (CKAT) to determine whether or not the students were of equivalent ability in chemistry. The pretest scores of the students were kept for comparison. The experimental group was given the treatment - that is, teaching the concept chemical kinetics using reciprocal peer tutoring for two weeks. Participating students were given orientation by their chemistry teacher at the beginning of the intervention regarding how to behave in groups, what academic, social and psychological benefits they will gain, and what expectations and requirements are there for assessment in the units. In order to make sure no student assume permanent position of knowledge dispenser or recipient; peer tutor's roles were regularly exchanged in reciprocal peer tutoring such that the student who plays the role of a tutor in one lesson plays the role of a learner in the next while another student be the tutor. Generally, the student tutors were notified in advance thereby enabling them prepare for the lessons. The control group was taught the same concept by the chemistry teacher using the lecture method for the two weeks. A posttest (CKAT) was given the two groups at the end of the two weeks and the posttest scores compared to determine the effect of the treatment (peer tutoring instructional method) on the subjects. Note that the items in the CKAT were reshuffled before use in the posttest. The same CKAT was reshuffled a second time and administered to the students a third time after four weeks from the date of the posttest. The third administration was to determine their retention.

The CKAT was the instrument used for gathering data from the students. It consisted of thirty (30) multiple choice questions drawn from chemical kinetics and related topics. Even though the items on the CKAT were obtained from past Senior School Certificate Examination (SSCE) questions, the researcher still subjected them to validation and to determining the reliability. For this study, the reliability coefficient was found to be 0.89 . The data collected from both the experimental and control groups were subjected to t-test statistics at $\mathrm{P}>0.05$.

\section{The Results}

The pretest and posttest data obtained were analyzed using t-test statistics and presented as follows:

Table 1: Pretest mean achievement scores of students in control and experimental classes

\begin{tabular}{lccccccc}
\hline & N & Mean & SD & Mean Diff & Df & T & P-Value \\
\hline Pretest Control & 41 & 5.41 & 1.99 & 0.19 & 84 & -0.49 & 0.65 \\
& & & & & & & \\
Pretest Expt & 45 & 5.60 & 1.89 & & & & \\
\hline
\end{tabular}

Table 1 shows that the pretest mean scores of students taught directly by chemistry teachers (the control) was 5.41 while that of the students taught using RPT (experimental) was 5.60. The mean difference was 0.19 which is negligible. The mean and standard deviation for the pretest control is $5.41 \pm 1.99$ while the mean and standard deviation for the pretest experimental group is $5.60 \pm 1.89$. The p-value is $0.65(>0.05)$. The null hypothesis failed to be accepted. Therefore, there is no significant difference between the pretest mean achievement scores of students taught chemical kinetics using RPT and those taught directly by teachers.

Table 2: Posttest mean achievement scores of students in control and experimental classes

\begin{tabular}{lccccccc}
\hline & N & Mean & SD & Mean Diff & Df & T & P-Value \\
\hline Posttest Control & 41 & 14.80 & 3.86 & 2.24 & 84 & -4.21 & 0.00 \\
& & & & & & & \\
Posttest Expt & 45 & 17.04 & 3.43 & & & & \\
\hline
\end{tabular}

Table 2 shows the result of the analysis of the posttest mean achievement scores of students in the control class and those taught chemical kinetics using RPT. The posttest mean achievement score of students taught directly by teachers was found to be 14.80 while that of the experimental class was 17.04 . The mean and standard deviation for the posttest control is $14.80 \pm 3.86$ while the mean and standard deviation for the posttest experimental group is $17.04 \pm 3.43$. The mean difference was 2.24 while the p-value is $0.00(<0.05)$. The null hypothesis was rejected. Therefore, there is a significant difference between the posttest mean achievement scores of students taught chemical kinetics using RPT and those taught directly by teachers. 
Table 3: Posttest mean achievement scores of male and female students in the experimental classes

\begin{tabular}{lccccccc}
\hline & N & Mean & SD & Mean Diff & Df & T & P-Value \\
\hline Posttest Male Expt & 24 & 17.25 & 3.56 & 0.45 & 43 & -0.747 & 0.464 \\
& & & & & & & \\
Posttest Female Expt & 21 & 16.80 & 3.34 & & & & \\
\hline
\end{tabular}

The result in Table 3 indicates that the mean difference between the male and female students in the experimental group is 0.45 . The standard deviation for the male experimental group is $17.25 \pm 3.56$ while the mean and standard deviation for the posttest experimental group is $16.80 \pm 3.34$. The p-value is 0.464 . There is no significant difference $(\mathrm{P}>0.05)$ between the posttest mean achievement scores of male and female students in the experimental group.

Table 4: Posttest mean retention scores of students in the control and those in the experimental classes

\begin{tabular}{lccccccc}
\hline & N & Mean & SD & Mean Diff & Df & T & P-Value \\
\hline Posttest Ret.Ctrl & 41 & 13.00 & 3.86 & 3.89 & 84 & -4.657 & 0.00 \\
& & & & & & & \\
Posttest Ret.Expt & 45 & 16.89 & 3.33 & & & & \\
\hline
\end{tabular}

Table 4 shows that the posttest mean retention score for the control group was 13.00 while that of the experimental group was 16.89 with a mean difference of 3.89 in favor of the class taught by RPT. The mean and standard deviation for the posttest retention control is $13.00 \pm 3.86$ while the mean and standard deviation for the posttest retention experimental group is $16.89 \pm 3.33$. The $\mathrm{p}$-value is $0.00(\mathrm{p}<0.05)$. Therefore, there is a significant difference between the posttest mean retention scores of students taught chemical kinetics using RPT and those taught directly by teachers.

Table 5: Posttest mean retention scores of male and female students the experimental classes

\begin{tabular}{lccccccc}
\hline & N & Mean & SD & Mean Diff & Df & T & P-Value \\
\hline Post Ret Male & 24 & 17.46 & 3.20 & 1.22 & 43 & 1.84 & 0.081 \\
& & & & & & & \\
Post Ret Female & 21 & 16.24 & 3.43 & & & & \\
\hline
\end{tabular}

Table 5 gives the mean and standard deviation for the posttest mean retention scores of the male students in the experimental group as $17.46 \pm 3.20$ while that of the female students in the experimental group is $16.24 \pm 3.43$. The mean difference is 1.22 and the $\mathrm{p}$-value is $0.081(\mathrm{p}>0.05)$. Therefore, there is no statistically significant difference between the posttest mean retention scores of male and female students taught chemical kinetics using RPT

\section{Discussion of Results}

One of the findings of the study is that there is a significant difference between the posttest mean achievement scores of students taught chemical kinetics using Reciprocal Peer Tutoring (RPT) and those taught directly by teachers. The students taught using RPT outperformed those in the control class - showing the effectiveness of RPT. The effectiveness of RPT in the teaching and learning has been established a number of researchers such as Campit and Cayabyab (2015) and Abdulraheem, Yusuf, and Odutayo (2017). They all reported a significant improvement in achievement of students in mathematics and economics respectively in classes where students were exposed to RPT. The students exposed to peer tutoring strategy performed better than students exposed to conventional teaching. There is significant difference between the achievements of students exposed to peer tutoring and those exposed to conventional teaching and the students exposed to peer tutoring had significantly higher achievement than those in conventional teaching. Marylnn and Bryan in Jibrin and Zayum (2012) investigated the effects of reciprocal peer tutoring on the academic achievement, self-efficacy and test anxiety of University students in Georgia and indicated that those exposed to peer tutoring performed better than those exposed to using lecture method in academic achievement. Miravet, Ciges, and García (2014) found that the academic benefit of RPT is different for the two group of students, and the extent of effect depends on the degree of feedback and support given. Furthermore, the effect of peer tutoring in enhancing academic achievement declines with increasing school levels. It was also reported that peer tutoring have stronger effects on social and psychological effects than academic gains (Bowman-Perrott, Greenwood, \& Tapia, Y., 2014). Despite all the inconsistent variations as to the degree of effectiveness of peer tutoring, researchers in the area acknowledged 
that it has more positive effects to all students at all levels of education in bolstering students' academic achievement, psychological, and social learning. Therefore, the use of peer tutoring instructional strategy has a significant effect on students' achievement in chemistry and it is an effective technique for increasing students' academic achievement and retention in chemical kinetics.

The study also found out that there is no significant difference between the posttest mean achievement scores of male and female students taught using reciprocal peer tutoring strategy. The same result was obtained for the retention test. This finding agrees with that of Abdulraheem, Yusuf, and Odutayo (2017) who established that peer tutoring had no gender bias with respect to improving students' academic performance in economics. Tella (2013), after finding it more effective than explicate teaching independent of the gender differences, recommended the use of peer tutoring as an interchangeable classroom methodology. Peer tutoring did not favor male over female or vice-versa, and improvement in the performance of students exposed to peer tutoring cannot be traced to gender. Oviawe (2008) had earlier reported no significant difference in the academic achievement in prevocational subjects and sciences of both male and female students exposed to peer tutoring. Others who found similar results include Imoko (2015) and Abidoye and Omotunde (2015). However, the result is contrary to the findings of Nkpa and Ocho (2009); Iyekekpolor (2010) and Adigwe (2015) who found in their various studies that there is a significant difference in the achievement of male and female students in chemistry and science examinations.

Another finding of the research is that there is a significant difference between the posttest mean retention scores of students taught chemical kinetics using RPT and those taught directly by teachers. This is in line with Ehirhime's (2020) finding that peer tutoring enhances academic knowledge retention among office technology and management students of polytechnic. Ding and Harskamp (2011) in a study on the collaboration and peer tutoring in chemistry laboratory education, also reported that the delayed post- (retention test) revealed that students who had been in the peer tutoring situation outscored those in the collaborative learning situation. Analysis of the post retention scores also revealed that there is no significant difference between the posttest mean retention scores of male and female students taught chemical kinetics using RPT. This means that the strategy is not only effective but is a gender friendly strategy which enhances retention of knowledge.

\section{Conclusions and Recommendations}

This study has established that reciprocal peer tutoring strategy enhanced the achievement of students in chemical kinetics more than the conventional teaching strategy. It is an effective instructional strategy that can be used to improve both male and female students' achievement and retention in chemistry at the senior secondary school level in Nigerian schools. From the results of this study, the researcher recommends the use of reciprocal peer tutoring in order to improve the achievement and retention of students in chemistry more so that the strategy is gender friendly. Chemistry teachers should be encouraged to use the strategy in addition to other student-centered strategies in the classroom. Workshops, seminars and conferences on the use of reciprocal peer tutoring and other innovative strategies should be organized for chemistry teachers. A follow up study should be conducted to find out the effect of varying reciprocal peer tutoring on students' achievement and retention in chemistry.

\section{REFERENCES}

Abdulraheem, Y., Yusuf, H. T., \& Odutayo, A. O. (2017). Effect of peer tutoring on students' academic performance in economics in Ilorin South, Nigeria. Journal of Peer Learning, 10, 95-102

Alemu, M. (2020). Improving secondary school students physics achievement using reciprocal peer tutoring: a multi-level quasi-experimental study. EURASIA Journal of Mathematics, Science and Technology Education, 16(4), em1832 ISSN:1305-8223 (online)

Ayuba, B. (2011) Impact of peer tutoring on the academic achievement in sciences among secondary school students within Bauchi Metropolis .Unpublished B. Tech (Ed) Project, Abubakar Tafawa Balewa University Bauchi.

Bowman-Perrott, L. J, Burke, M. D., Zhang, N., \& Zaini S. (2014). Direct and collateral effects of peer tutoring on social and behavioral outcomes: a meta-analysis of single-case research. School Psychology Review, 43(3), 260-285. Retrieved from https://www.researchgate.net/publication/282502483

Campit, J. B., and Cayabyab, J. (2015). The effect of peer tutoring on achievement of students in discrete structures. Asia Pacific Journal of Multidisciplinary Research, 3(5), 8 - 12 
Cheng, Y.-C., \& Ku, H.-Y. (2009). An investigation of the effects of reciprocal peer tutoring. Computers in Human Behavior, 25(2009), 40-49. https://doi.org/10.1016 /j.chb.2008.06.001

Ding, N. \& Harskamp, E. G. (2011). Collaboration and peer tutoring in chemistry laboratory education. International Journal of Science Education, 33(6), 839-863

Dufrene, A.B., Noell, G.H., Gilbertson D. N. \& Duhon G .J. (2005). Monitoring implementation of reciprocal peer tutoring: Identifying and intervening with students who do not maintain accurate implementation. School Psychology Review, 34 (1), 74-86

Egbochuku, E. O, Obiunu, J .J. (2006). The effects of reciprocal peer counseling in the enhancement of selfconcept among adolescents. Education, 126 (3), 504-511

Ehirhime, P.E (2020). Effect of peer tutoring on students' knowledge retention in office technology and management in polytechnics in South West Nigeria. Advances in Social Sciences Research Journal, 7(9), 892900

Fatokun, K. V.; Onwoke, J. E,; \& Hudu, S. (2018). Effects of cooperative learning and peer tutoring strategies on chemistry students' achievement and retention in redox sreaction. Researchjournali's Journal of Education, $6(11)$

Federal Government of Nigeria. (2008). National Policy on Education. Lagos: NERDC Press

Gillies, R. M., \& Ashman, A. F. (2003). An historical review of the use of groups to promote socialization and learning. In R. M. Gillies \& A. F. Ashman (Eds.), Cooperative Learning: The Social and Intellectual Outcomes of Learning in Groups (pp. 1-18). London: Routledge Falmer.

Gongden, E. J. (2015). Comparative effects of two metacognitive instructional strategies on gender problem solving abilities in selected chemistry concepts. Unpublished Ph.D Thesis, A.T.B.U Bauchi, Nigeria.

Gongden, E. J., \& Gongden, E. E. (2019). Effects of computer assisted instruction on male and female students' achievement in basic science in Jos metropolis, Nigeria. American Research Journal of Humanities Social Science, 2(1), 27-35

Isah, A. (2013). Attitude towards science and achievement of female students in Basic Science in Nasarawa State. Unpublished M.Sc. Dissertation., Nasarawa State University, Keffi

Jegede, S.A. (2007). Students' Anxiety towards learning of Chemistry in some secondary schools. Journal of Educational Research and Review, 2(7): 193 -197.

Jibrin, A.G. \& Zayum, S. D. (2012). Effects of Peer Tutoring Instructional Method on the Academic Achievement in Biology among Secondary School Students in Zaria Metropolis, Nigeria. Journal of Research in Education and Society; 3(2), $14-18$

Miravet, L. M., Ciges, A., \& García, O. (2014). An experience of reciprocal peer tutoring at the university. Procedia - Social and Behavioral Sciences, 116(2014), 2809-2812. https://doi.org/10.1016/j.sbspro.2014.01.661

Neugebauer, J., Ray, D. G., \& Sassenberg, K. (2016). When being worse helps: The influence of upward social comparisons and knowledge awareness on learner engagement and learning in peer-to-peer knowledge exchange. Learning and Instruction, 44, 41-52. https://doi.org/10.1016/j.learninstruc.2016.02.007

Nnorom.N.R. (2015). Effect of cooperative learning instructional strategy on senior secondary school students Achievement in Biology in Anambra state. Nigeria Internal Journal for Cross-disciplinary Subject in Education (IJCDSE) special Issue Vol.5

Nworgu, B. G. (2006). Educational Research: Basic Issues and Methodology (2 ${ }^{\text {nd }}$ Ed.). Enugu: University trust publishers 
Ogbuanya, T.C, Bakare, J.A \& Igweh, A.U (2009). Reciprocal peer tutoring and academic achievement of students in electronics in technical colleges in south west Nigeria. Nigerian Vocational Journal, 14 (1), 98-106.

Ojokuku, G. O (2012). Understanding Chemistry for Schools and Colleges. Press-on-ChemResources.

Okparaugo, O. J. (2017).The Effect of Peer Group Tutoring on the Academic Performance and Retention of Biology students in Katsina State. Retrieved from https:/www.academia.edu/44546687/ The Effect of Peer Group Tutoring on the Academic Performance and Retention of Biology students in Katsina State on August 1, 2021

Oludipe, D. B. (2007). Impact of reciprocal peer-tutoring on secondary school students' achievement in large physics classes in Nigeria. Ubiquitous Learning: An International Journal, 1 (2), 13-18.

Oviawe, J. I. (2008). Effect of peer tutoring assisted instruction on students' academic achievement in introductory technology. FCT Education Secretariat Journal of Curriculum studies and Instruction, 1(1), 77-84

Paul G., Lisa F. \& Vanesa, T. (2006). Effects of Peer Tutoring, Attitude and Personality on Academic Performance of First Year Introductory Programming Students. 36th Frontiers in Education Conference ,October 28-31 at San Diago.

Samba, R.M.O., \& Eriba.J.O. (2012).Innovative approaches in teaching difficult science concepts, Makurdi Destiny ventures.

Sani, U.T. (2015). Effects of cooperative learning strategy on senior secondary school students' performance in quantitative Chemistry in Kebbi State, Nigeria.Journal of Education \&Social Sciences, 1(2).

Tella, A. (2013). The Effect of Peer Tutoring and Explicit Instructional Strategies on Primary School Pupils Learning Outcomes in Mathematics. Bulgarian Journal of Science and Education Policy, 7(1), 5-25.

Topping, K. J. (2005). Trends in Peer Learning. Educational Psychology, 25(6), 631-645. https://doi.org/10.1080/01443410500345172

Vygotsky, L. S. (1978). Mind in society: The development of higher psychological processes. In M. Cole, V. John-Steiner, S. Scribner, \& E. Souberman (Eds.). Cambridge, MA: MIT Press.

WAEC (2015). Chief Examiner's reports for May/June WASSCE. Lagos: Retrieved at http// www: waecnigeria.org. history.htm

WAEC (2016). Chief Examiner's reports for May/June WASSCE. Lagos: Retrieved at http// www: waecnigeria.org. history.htm.

WAEC (2017). Chief Examiner's reports for May/June WASSCE. Lagos: Retrieved at http// www: waecnigeria.org. history.htm

WAEC (2018). Chief Examiner's reports for May/June WASSCE. Lagos: Retrieved at http// www: waecnigeria.org. history.htm 